\title{
Geoclogs: The Potential of a Special Economic Zone in Halmahera Utara Regency
}

\author{
${ }^{1}$ Magdalena Wullur* \\ Program Studi Manajemen \\ Fakultas Ekonomi dan Bisnis \\ Manado, Indonesia \\ wullurmagdalena@yahoo.com
}

\author{
${ }^{2}$ Joyce C Kumaat \\ Program Studi Geografi \\ Universitas Negeri Manado \\ Tondano, Indonesia \\ joykekumaat@unima.ac.id
}

\author{
${ }^{3}$ Apeles L Lonto \\ Program Studi PPKN \\ Universitas Negeri Manado \\ Tondano, Indonesia \\ lexylonto@unima.ac.id
}

\begin{abstract}
This study aims to review the economic potentials of Halmahera Utara Regency with Geo cluster, geologistic, and geostrategy variable approach, these three variables named geoclogs are still minimal terms discussed in previous studies. Geoclogs defined as a geographical or geographic approach by emphasizing the relationship between economic and financial investigations. Geocluster's potential analysis shows that Halmahera Utara Regency has a very creative community. Handicraft mat pandan from Halmahera Utara is very famous until exported out of the country. Almost all people in Halmahera Utara have a mat making skill. This skill is inherited gradually from generations. This product is usually used in traditional wedding ceremonies in Halmahera Utara. Geologistic potentials, Halmahera Utara, will be very fast forward if transport there repaired. Not only ground transportation but air transport and sea transportation. Halmahera Utara has a very extraordinary natural beauty, and if the access to transportation to go to the place is smooth, more and more tourists, both local and international, so encapsulate become one of the factors for the economic growth of Halmahera Utara Regency. Potential Geostrategy, this district is a remote or distant region, both from the capital city and provincial capital, Sofifi. However, its position has a high bargaining value because it is on the Pacific Rim, dealing directly with countries in the Pacific recesses, let alone ASEAN countries. That is, Halmahera Utara has a value of geostrategic worth reckoned, in addition to the abundant natural resources.
\end{abstract}

Keywords: geo cluster, geologistic, geostrategy

\section{INTRODUCTION}

Geo cluster [1], geologistic [2], and geostrategy [3], then these three variables named geoclogs are still minimal terms discussed in previous studies. Geoclogs defined as a geographical or economic approach by emphasizing the relationship between economics and money studies. This research, dissociations the defendant geoclogs, about the potential, challenges, and the direction of geoclogs policy against the Special Economic Zone (SEZ) and geoclogs spatial information. The research emphasis on the geoclog variable further understood that the research is still at the level of proving the actual concept and mapping, not on the confirmation of the variable

Geoclogs as a new concept integrates three (3) economic spatial planning variables: geo cluster, geologistic, and geostrategy. By [1], [4], variable geo cluster defined as the economic geography towards global competition by focusing on site theory as a source of its excellence [5], while [6] emphasizing competitive terms next, by [7], making the geo cluster is focused on intercompany relationships as well as the relationship between buyer and supplier, training or research, as well as product marketing cooperation. Variable geologistic is the earth science that learns the management process of the transfer and storage of goods and information related to the source of the end consumer effectively and efficiently [2]. Logistics also includes integration between in lineups, finance, and materials as well as stockpile logistics reserves [8], [9].

Geologistic is how the global process of manufacturing and services moved from upstream to downstream, built with the trust, commitment, and action of each party along the displacement chain [10], [11]. The last is the geostrategy variable, defined as a method or rule to achieve goals and objectives through a development process that gives directions on how to create a scalable and imaginary development strategy and to create a better, safer, and dignified future [12], [13] .

Therefore, geostrategy Indonesia as a way or method in utilizing all the geography of the country of Indonesia in determining the policy, direction, and facilities in achieving the objectives of the entire nation by the principle of humanity and social Justice [14]. This study aims to review the economic potentials of Halmahera Utara Regency with geo cluster, geologistic, and geostrategy variable approach, these three variables named geoclogs are still minimal terms discussed in previous studies.

\section{RESEARCH METHODS}

This research refers to the kind of qualitative research with socio-spatial [15]-[17] and descriptive [12], [18], [19]. A socio-spatial approach is a research approach that illustrates many aspects of community activities on the social use of space [15]-[17]. The descriptive method is a type of research that seeks to describe a phenomenon or event as it is [20]. Human behavior can be observed, while the aim is to define precisely the situation [21].

This method of research to analyze satellite imagery interpretation into geographic information system [22][24]. This method of research to analyze satellite imagery interpretation into spatial analysis [25]. 


\section{Place and Time research}

The location of this research is in Halmahera Utara Regency (Figure 1), North Maluku Province, and the research object is mapping the archipelago area based on the research sector. The time utilized for the data collection required is October 2019 until December 2019.

\section{Data Source}

The data sources in this study are primary and secondary data [26]. Declaring primary data is a source of research data obtained directly from the original (not through intermediate media). The primary data collected in this research is data survey results in Halmahera Utara, find out the point of potential locations of Halmahera Utara and area the potential areas to be proposed cakes.

Primary Data obtained based on the results of a survey of the coordinates of the possible location of the site in Halmahera Utara Regency. Secondary data is generally evidence, records, or historical reports that must arrange in archives that are published and unpublished [26]. The secondary data [26] obtained in this research is the potential data of Halmahera Utara Regency, as seen from the advantages of geo cluster, geologistic and geostrategy.

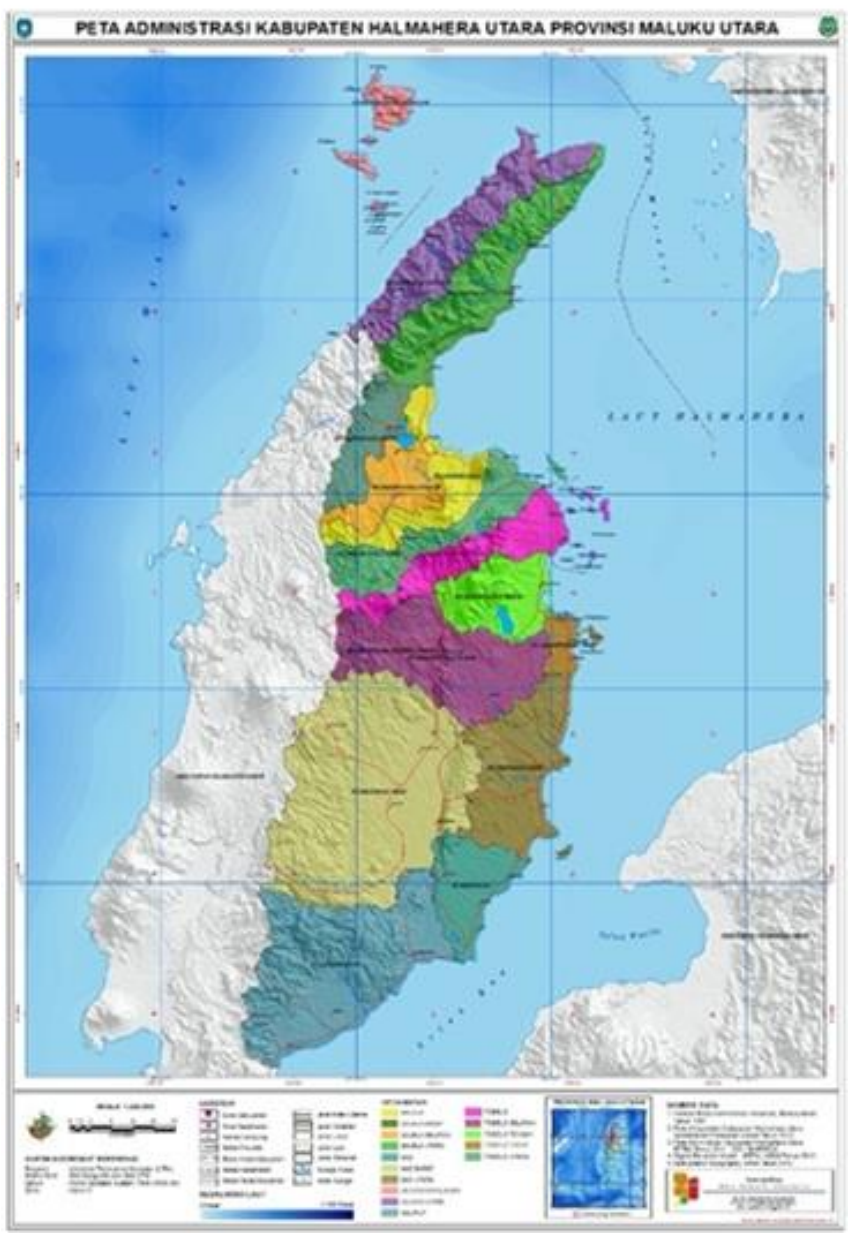

Figure 1. Administrative Map

\section{Data Analysis Techniques}

The analytical techniques used in this research are geographic information systems (GIS) analysis techniques that can create models that provide an overview, explanation, and estimate of an exact condition [22]-[24]. GIS analysis techniques for mapping the potential of Halmahera Utara to find a strategic location to write the economic area. Data processed using one of the software analyses tools, ArcGis 10.6.1 [27].

\section{RESULTS AND DISCUSSION}

Special Economic Zone (SEZ), was developed to promote economic growth and increase investment nationwide. SEZ is needed to boost economic growth so that all activities that support trade and investment are focused so that the results are more optimal. Therefore, the SEZ does not apply the same special provisions between each region related to taxation, licensing, immigration, and employment. In this region, all goods will not be subjected to customs duties, VAT and excise, to encourage investors will also apply to the ease of investing through the comfort of effort, reduction of corporate taxes, and looseness of foreign exchange control.

The purpose of the establishment of economic areas, including to increase investment, increase the absorption of human resources either directly or indirectly, increased foreign exchange implementation as a result of exports. Besides, it improves the competitive advantage of local products, as well as utilizing regional resources and encourages enhancing the quality of human resources through technology transfer.

\section{Potentials: Geocluster, Geologistic, Geostrategy}

Halmahera Utara Regency has a very creative community. Handicraft mat pandan from Halmahera Utara is very famous until exported out of the country. Almost all people in Halmahera Utara have a mat making skill. This skill is inherited gradually from generations. This product is usually used in traditional wedding ceremonies in Halmahera Utara. Some other handicrafts in Halmahera Utara are saloi (rear baskets), tolu (cap), sisiru/aya-aya (filters), and others. With the power of the resource, and if the fund managed adequately, it could help the economic growth of Halmahera Utara Regency. These things prove as good resource skills in Halmahera Utara [29].

Halmahera Utara would be very fast forward if transport there repaired. Not only ground transportation but air transport and sea transportation. Halmahera Utara has a very extraordinary natural beauty, and if the access to transportation to go to the place is smooth, more and 
more tourists, both local and international, so encapsulate become one of the factors to Halmahera Utara Regency Economic growth.

It is a remote or remote area, both from the national capital and the provincial capital, Sofifi. However, its position has a high bargaining value because it is on the Pacific Rim, dealing directly with countries in the Pacific recesses, let alone ASEAN countries. That is, Halmahera Utara has a value of geostrategic worth reckoned, in addition to the abundant natural resources.

\section{Challenges going forward: Geocluster, Geologistic, Geostrategy}

Halmahera Utara will be very advanced if the construction very well organized and grouped. The meaning here is to advance Halmahera Utara need to be prioritized grouping in coordinating the development in Halmahera Utara. The gathering or distribution of priorities in the event in Halmahera Utara will help the government and society because the event will be well structured so that there will be no overlap. If development using such priorities can run well, and infrastructure built well, then Halmahera Utara is potentially a significant potential to become a very advanced district see resources in Halmahera Utara, which is very much. Post-conflict in Halmahera Utara is a lot of damaged infrastructure. There is still much postconflict debris scattered.

The community welfare of Halmahera Utara is also much expected. Children, there have not received a highquality education. Parents are not fully aware of the importance of education for their children. Also, because Halmahera Utara is still a new area because not long ago, the focus of the central government has not been in Halmahera Utara. Development in Halmahera Utara is still not going well. There are still many things that need to repair to advance Halmahera Utara Regency. And all good potentials are also resources in Halmahera Utara that have not appropriately managed.

No adequate transportation providing for unrestricted mobility in Halmahera Utara is one of the biggest challenges to be faced. Especially access to sea transportation to the islands in Halmahera Utara is still somewhat slight. And the shipment available for crossing is still quite expensive. Also, people living in lagging and the remote regions are still complicated to enjoy decent transportation. Logistics processes such as freight, warehousing, and information in Halmahera Utara are also far from the word forward.

Adequate and competitive human resources do not yet support this potential geostrategy. The indicator is its relatively low Human Development Index (HDI), 69.98 [28]. It is below the national average, 73.29. To realize the robust and advanced Indonesia, it needs by people who are intelligent and highly competitive. It can initiate by strengthening the child's ability through early childhood education (PAUD). Based on data from the General Directorate of Early Childhood Education and Community Education of the Ministry of Education and Culture (Kemdikbud) in 2013, from 197 villages in Halut, the number of communities that had a new PAUD 112. That is, there are still 85 villages that do not have them. Only two sub-districts already have PAUD in each town, namely East Tobelo District and West Galela. Other sub-districts have not reached the target of 100 percent, such as the two sub-districts.

The district of Kao and Kao Gulf, for example, has only reached 42.86 percent and 36.36 percent. North Loloda Sub-district was even still in the position of 27.78 percent, the lowest among the other districts. Of the 18 villages in the subdistrict, 13 communities did not have a PAUD. At the North Maluku province level, the percentage of the town that has PAUD in Halut district includes low, only 48.22 percent. Meanwhile, in other regions, such as Halmahera Tengah (Central Halmahera) and Tidore Islands, have reached 72.92 percent and 72.22 percent. The condition indicates that the Halut district still must struggle to realize the expected community.

\section{Policy direction: Geocluster, Geologistic, Geostrategy}

After being appointed and officially became regent of Halmahera Utara on 12 August 2005, proposed priority programs to build Halmahera Utara as well as its birthplace. As a first step, he established the vision to build Halmahera Utara in the future, "safe Halmahera Utara, fair, peaceful and prosperous in a true family atmosphere, forward and able to compete and remain in the frame of the unitary Republic of Indonesia." Adhering to the vision, several priority programs. In the year 2006, there were 11 priority programs. Among them are the regional development programs of Kecamatan and rural and institutional strengthening. It also complements the facilities of work and office as well as the development of government physical infrastructure. To support economic access, also build a foundation.

Even assist in the rehabilitation of worship facilities. Meanwhile, in 2007, it prioritized six development programs. Among them: accelerate infrastructure development, increase economic growth, increase public access to education and health services. It also prioritizes poverty alleviation and quality of life improvement programs.

Halmahera Utara is geologistic, gradually built the disadvantaged and remote area infrastructure, by applying schemes such as pioneering subsidies to transportation and the village's entrance electricity program. For the smooth entry of information in Halmahera Utara, the technology utilization program launch. 


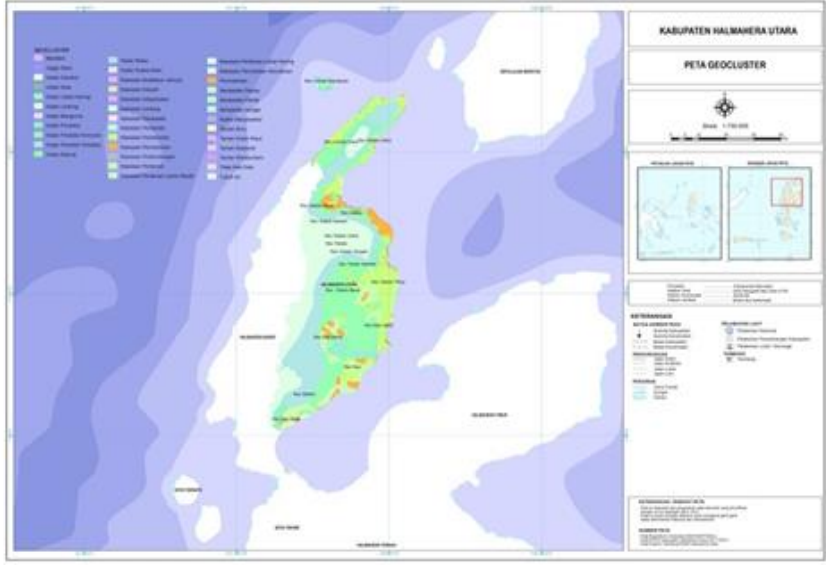

Figure 2. Map of Geocluster Halmahera Utara

The first thing to do is to install the internet network in government offices and some schools. To overcome the problem of warehousing i.e., the products of the community that not sold out, empowering cooperatives and small enterprises that aimed to contribute to the growth of the regional economy, job creation, and enhancement of competitiveness. To support the smooth transportation of the land, it also builds road access to economic activities. Also, build passenger and freight terminals. And for sea transportation, the Tobelo crossing port that serves the crossing tracks of Tobelo-Morotai and Tobelo-Subaim is better laid out because it has a very strategic potential. For the port that serves the trade that is the port of Tobelo, Port of Gorua, Wosia Port, for Air transport Halmahera Utara Regency doing the construction of Kuabang Airport (Kao) and Gamarmalamo Airport (Galela).

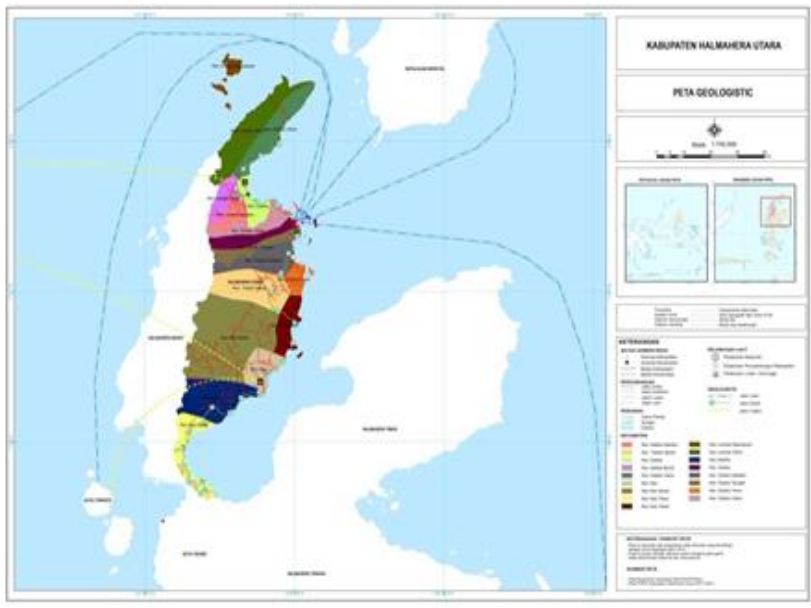

Figure 3. Map of Geologistic Halmahera Utara

The primary strategy assignment, along with its target indicators, is a policy to address geostrategy challenges. The five main strategies are:

First, realize the government entrepreneur. To make it happen, the entire SKPD implements public service operational standards with scalable and integrated performance.

Second, improve the quality of human resources. There are many efforts undertaken by the
Government in this regard. Among them, all school-age children can complete SLTA minimum education and master english, computer, and entrepreneurship. Low-income families also get health and education services. Health facilities must meet quality standards. The family also expected to have a nutritional awareness and apply small family norms of happy and prosperous families. Each region also has production training centers according to the region's flagship commodities.

Third, build a reliable infrastructure. All development is implemented based on RTRW, which based on tourism and agroindustry.

Fourth, powering the latest technology for cuttingedge technologies in the processing of excellent commodity marketing.

Fifth, grow the economy-based people of the commodity. With that purpose, each sub-district has superior merchandise supported by facilitating financing, marketing and entrepreneurship assistance, and production technology.

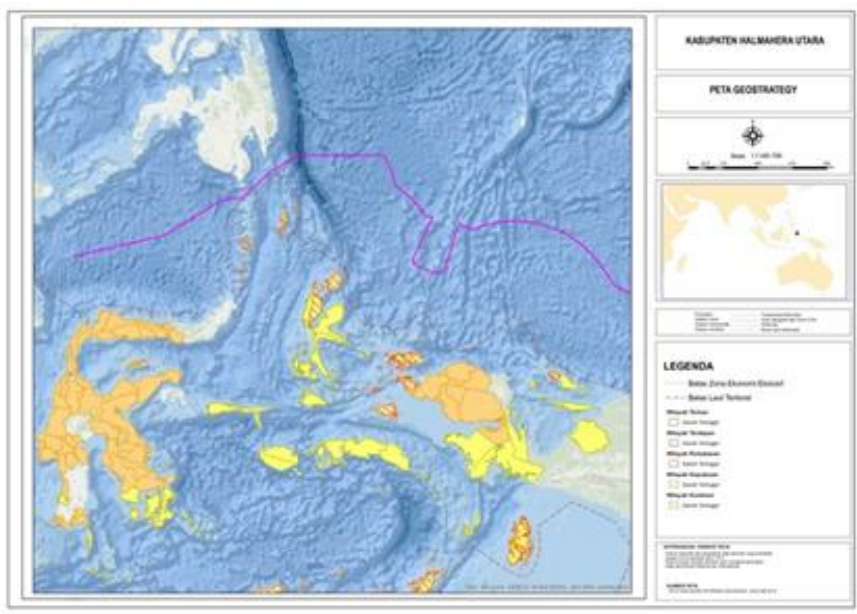

Figure 4. Map of Geostrategy Halmahera Utara

\section{CONCLUSION}

Geocluster is a geographical framework with no limitations. Geoclusters can easily take shape even with geographical differences, not only because they defined within the same area but because of economic and business bonding, making connectivity between one region and another.

Geologistic is the earth science that learns the management process from the transfer and storage of goods and information related to the source of the end consumer effectively and efficiently. News, finance and materials, and logistics reserves.

Geostrategy is a geopolitical branch that relates to strategy. 
Geoclogs is the basic concept of forward-thinking to explore the geographic location of Halmahera that is owned by the future. This writing is more specific to geo cluster, geologistic and geostrategy of the development of particular economic areas in Halmahera Utara, in the form of geography and some science associated with geography, which by starting the understanding of the very conventional and there are broad areas that follow the development of the time, give confidence to us what we can do In the future.

\section{REFERENCES}

[1] M. M. Sesana, B. Cuca, G. Iannaccone, R. Brumana, D. Caccavelli, And C. Gay, "Geomapping Methodology For The Geocluster Mapping Tool To Assess Deployment Potential Of Technologies For Energy Efficiency In Buildings," Sustain. Cities Soc., Vol. 17, Pp. 2234, 2015.

[2] S. I.G., "Geologistic Strategies Of Tourist And Hotel \& Restaurant Business Development In Overtourism Conditions," Sci. Bull. Kherson State Univ. Ser. Geogr. Sci., 2019.

[3] M. P. Fronda, "Hannibal: Tactics, Strategy, And Geostrategy," In A Companion To The Punic Wars, 2011.

[4] B. G. Jacob, J. A. Morris, E. X. Caamano, D. A. Griffith, And R. J. Novak, "Geomapping Generalized Eigenvalue Frequency Distributions For Predicting Prolific Aedes Albopictus And Culex Quinquefasciatus Habitats Based On Spatiotemporal Field-Sampled Count Data," Acta Tropica. 2011.

[5] R. Horner, "Beyond Facilitator? State Roles In Global Value Chains And Global Production Networks," Geogr. Compass, 2017.

[6] D. Herbert, "Book Review: A Geography Of Heritage: Power, Culture And Economy.," Prog. Hum. Geogr., 2001.

[7] L. Castro, "Journal Of Knowledge Management"Sourcing Knowledge For Innovation: Knowledge Reuse And Creation In Project Teams" Strategizing Across Boundaries: Revisiting Knowledge Brokering Activities In French Innovation Clusters," J. Knowl. Manag. Iss J. Knowl. Manag., 2015.

[8] G. Campanelli, M. Cavalli, V. Bertocchi, And C. Sfeclan, "Logistics," In Management of
Abdominal Hernias, 2013.

[9] G. Kovács And K. M. Spens, "Humanitarian Logistics In Disaster Relief Operations," Int. J. Phys. Distrib. Logist. Manag., 2007.

[10] D. J. Bowerson, D. J. Closs, And M. B. Cooper, "Supply Chain Logistics Management," McgrawHill \International Edition. 2013.

[11] Dynamics In Logistics. 2011.

[12] S. Mambu And M. Wullur, "Peta Potensi Halmahera Utara Menuju Kawasan Ekonomi Khusus," J. Ris. Ekon. Manajemen, Bisnis dan Akunt., 2017.

[13] J. Kumaat And M. Wullur, “Analisis Ekonomi Dan Daya Dukung Kawasan Ekowisata Pulau Kecil: Studi Kasus Pulau Mahoro Kabupaten Kepulauan Sitaro," Zenodo, Jul. 2017.

[14] M. Wullur And W. Wardaya, "Praktik Manajemen Rantai Pasok Dan Teknologi Bisnis Berbasis Elektronik Sebagai Pemoderasi Perusahaan Manufaktur," J. Manaj. Transp. Dan Logistik, 2017.

[15] T. Cassiers And C. Kesteloot, "Socio-Spatial Inequalities And Social Cohesion In European Cities," Urban Stud., 2012.

[16] I. Szmigin, A. Bengry-Howell, Y. Morey, C. Griffin, And S. Riley, "Socio-Spatial Authenticity At Co-Created Music Festivals," Ann. Tour. Res., 2017.

[17] J. T. Murphy, "Human Geography And SocioTechnical Transition Studies: Promising Intersections," In Environmental Innovation And Societal Transitions, 2015.

[18] C. Kothari, Research Methodology: Methods And Techniques. 2004.

[19] A. Dassen And K. Gemenis, "Social Science Methodology: A Unified Framework," Acta Polit., 2012.

[20] B. Taylor, "Phenomenology," In Qualitative Research In The Health Sciences: Methodologies, Methods And Processes, 2013.

[21] A. Giorgi, "The Descriptive Phenomenological Psychological Method," Journal Of Phenomenological Psychology. 2016.

[22] S. Wang, G. Ding, And M. Zhong, "Big Spatial Data Mining," In Proceedings - 2013 Ieee International Conference On Big Data, Big Data 
2013, 2013.

[23] S. C. Guptill, "Spatial Data," In International Encyclopedia Of The Social \& Behavioral Sciences: Second Edition, 2015.

[24] S. Wang And H. Yuan, "Spatial Data Mining," Int. J. Data Warehous. Min., 2014.

[25] S. Coast, "Openstreetmap," Bull. Soc. Cartogr., 2005.

[26] A. Latham, "Key Methods In Geography," In Geographical Research, 2010.

[27] Esri, “An Introduction To Sampling/Monitoring
Networks-Help | Arcgis Desktop," Arcmap 10.6. , 2019. .

[28] [Bps] Badan Pusat Statistik, "Berita Resmi Statistik," Bps.Go.Id, 2019.

[29] M. Wullur and J. C. Kumaat, "Sistem Informasi Geografi dan Rantai Pasok: Bagaimana Geografi Dapat Memperkuat Analisis Rantai Pasok?,"

Jurnal Episentrum, 2020. 